\title{
Devolution in Kenya: The Good, the Bad and the Ugly
}

\author{
Samuel Ngigi, PhD \\ Lecturer at School of Journalism and Mass Communication, University of Nairobi \\ Doreen Nekesa Busolo \\ Researcher at Centre for Development Research and Strategy
}

\begin{abstract}
The adoption of devolved system of government in Kenya was a desire of citizens who wanted access to public services closer to them. The objects of devolution as provided for in Articles 174 and 175 of the Constitution about promotion of democracy and accountability in the exercise of power, fostering national unity by recognizing diversity, enhancing people's self-governance, enabling communities manage their own affairs, protecting and promoting interests and rights of minorities and the marginalized and ensuring equitable sharing of resources. To achieve these, there must be framework put in place and enabling environment provided to all stakeholders involved in implantation of devolution. However, the environment for implementation of devolution has not been smooth due to various challenges experienced for the past five years. Issues like disagreements between the National Government and County government over funding for County functions, poor or absence of consultation on matters that affect County Governments, little technical support for the implementation of functions, insufficient allocations and delayed disbursements of funds to Counties by the National Treasury, lack of capacity and skills to deliver services, corruption, lack public participation, gender inequality are some of the challenges this paper is going to analyze. It is clear that these challenges have affected the implementation of devolution in Kenya. To achieve the goal of devolution there should be a better working relationship between the two levels of government. Parliament, County Governments, the IGRTC, the Ministries, Independent Offices and Commissions, civil society- all should work together in the spirit of Article 6(2) for the good of devolution.
\end{abstract}

DOI: $10.7176 / \mathrm{PPAR} / 9-6-02$

Publication date:June $30^{\text {th }} 2019$

\subsection{History of Devolution}

Devolution in Kenya is traced back in 1963 when the country got its independence however; this was short-lived due to lack of substantive founding in the philosophies of either KADU or the KANU party which was responsible of implementing it (SID 2011).

The Constitution of Kenya, 2010 created a decentralized system of government wherein two of the three arms of government; namely the Legislature and the Executive are devolved to the 47 Political and Administrative Counties as provided for under Article 6. The primary objective of decentralization was to devolve power, resources and representation down to the local level. Devolution was seen to be the key to unlocking Kenya's economic potential through distribution of responsibilities.

Decentralization permitted Counties to identify problems, make policies, plan, and collect revenue, execute budget, accounting, auditing and monitoring and evaluation and citizen participation in decision-making(SID 2011). Article 174 of the Constitution identified several objects of devolution which include giving powers of selfgovernance to the people and enhance their participation in the exercise of power in making decisions affecting them. The Article also recognized the rights of communities to manage their own affairs and to further their development.

The forty seven County governments came into operation in 2013. This marked a complete departure from the national government system that has been in operation since independence (CRA). The national government was characterized with a myriad of challenges that included marginalization, vast inequalities, and mismanagement of resources and exclusion of many communities from the decisions process. Institutions as well as policies and regulation were established to enhance the functioning of devolved system of government. For instance The Commission on Revenue Allocation (CRA), is mandated to recommend the basis for equitable sharing of revenues raised nationally between the national and the county governments.

The Commission established under Article 215 of the Constitution of Kenya 2010 plays a significant role of recommending on matters concerning the financing and financial management of both the national government and county governments. The transition to devolved system is a process that will take time as revealed by UNDP (2015). The report identified policy gap both at national and county level. There is need for policy framework to ensure that devolved institutions are functioning well and grounded on strong legal foundations. This and other challenges have impacted on devolution process. 


\subsection{Advantages of Devolution}

So, what is the importance of devolution in Kenya? From the need for equal distribution of resources and powers to public participation, here are some of the advantages of decentralization in Kenya.

\subsection{Equitable Distribution of National Resources}

Previously, most of the resources including public institutions were in the major urban centers and cities. But, with devolution, each county has equal chances of growth as the share of resources is equal. Equitable share according to Hope (2014) is governed by a set of criteria that include: economic disparities within and among counties and the need to remedy them; the desirability of stable and predictable allocations of revenue; and the need for economic optimization of each county and to provide incentives for each county to optimize its capacity to raise revenue.

Currently, the resources are allocated to counties based on a weighted formula: population, 45 percent; poverty rate, 20 percent; land area, 8 percent; fiscal responsibility, 2 percent; and a basic equal share of 25 percent (Kimenyi 2013). Twenty five percent of the revenues are to be shared equally among all counties. Two percent of revenue is provided as an incentive for fiscal responsibility, and will be initially shared equally among the counties. Under the fiscal responsibility parameter, counties that manage their resources better and are more effective in mobilizing their own resources should be rewarded by receiving a higher share of the resources.

The formula seeks to equalize allocations based on proximate measure of deprivation (poverty rates) and costs of delivering services (land area, size of population) (Kimenyi 2013). The Division of Revenue Act, 2013 provides for the equitable division of revenue raised nationally between the national and county governments. This formula according to Kinuthia (2016) was adopted by a number of counties from the Commission on Revenue Allocation's (CRA).

Elgeyo Marakwet County through the Elgeyo Marakwet County Equitable Development Act, 2015 works towards realizing equitable share of resources in the county. This Act was developed to provide for the realization of equal and equitable allocation of resources for development projects within wards and also to provide for the establishment of a ward development and project implementation committees thus giving them powers, functions and responsibilities to deliver services and for connected purposes.

Kivoto (2016) has different opinion concerning equitable share of resources when he argues that some counties have high investment returns as compared to those with high poverty index and low human resource personnel. Kimenyi (2013) argument conquers with Kivoto stating that although the actual cost of medicine for instance may be the same across all of Kenya's counties, however the total cost of treatment vary across the various jurisdictions.

Council of Governors Strategic Plan 2017-2022 intends to intensify its commitment to promoting adequate financing for devolved functions as a matter of common interest for consideration by the County Governments. The focus is on expenditure management, resource mobilization both internal and external and debt management.

Report by Development Initiatives Organization (2017), revealed that the national government allocated more than twice the constitutional requirement 15 percent in equitable share to county governments for $2017 / 18$. In 2017/18, equitable revenue share allocated to counties amounted to Ksh 291.1 billion, representing an increase by $7.9 \%$ and $15.2 \%$ from $2015 / 16$ and 2016/17.

The Treasury proposes Ksh. 299 billion in equitable share and Ksh 13 billion in conditional allocations, more than what was published by the National Assembly. In addition, the conditional grants to counties have increased by close to $50 \%$ in $2017 / 18$ compared to the previous year.

\subsection{Platform for Economic and Social Development}

With the devolved systems, it is easier to achieve growth both at national and county development. As county headquarters and centers develop, new opportunities for employment and investments arise paving the way for more significant progress. Currently, county governments are implementing growth strategies that aim at improving the living standards of its people. Early 2018, Makueni county launched its Universal Health System to make affordable care achievable in the area

KIPPRA (2018) report on assessment of healthcare delivery in Kenya under devolved system emphasized that, there is significant improvement in the health sector performance. The report pointed out improved child survival over the last five decades, with reduction of under-five, infant, neonatal and maternal mortality. The nutrition status of children also improved. There is significant decline in communicable disease and the HIV prevalence also declined marginally with the country governments achieving its ART coverage target of 1.03 million people in 2016.

The report further revealed that County governments have significantly invested into increasing the number of health facilities especially those at lower levels. They are also working towards enhancing provision of medical supplies and maintenance of equipment.

County governments can now manage and develop their own affairs as well as foster social, economic and 
political development. People are empowered to make decisions on issues affecting them through participation. The inclusion of local communities will help to fight marginalization thus embracing unity.

Mid Term Evaluation Report by UNDP (2017) on the integration support program to the devolution process in Kenya revealed that, Kenya's urban centers account for more than 65 percent of gross national income and as Kenya is increasingly becoming urban, cities and towns are likely to increasingly play their role of drivers of national economic and social development. The revenue generating mechanisms for devolution have strong effects on economic growth and service delivery. The income is likely to increase through local economic development initiatives.

In addition, Council of Governors (CoG) partnered with the Swedish Association of Local Authorities and Regions (SALAR) and its subsidiary SKL-International, to implement a capacity building project aimed at promoting sustainable urbanization in Kenya. The three and half year "Kenya SymbioCity Program will improve the economy by creating employment.

The Macroeconomic Framework in second medium term plan 2013-2017 aimed at stabilizing the economy through sustained growth in agriculture, manufacturing, and service sectors. This has led to conflict between Counties expansion of boundaries to secure resources that are economically beneficial to the County. For instance the case Makueni boundary dispute where both counties wanted to enjoy fiscal and administrative autonomy while as well as secure pasture and political autochthony as pointed out by Kivoto (2016). However he concludes that some counties have formed economic blocs to ease economic cost and sustainability of producing some raw materials.

Kenya School of Government and the Ministry of Devolution (2015), emphasized on strengthening public participation and governance to accelerate growth and address long-standing inequalities in economic opportunities, investment, and service delivery in different parts of the country.

County governments have introduced revenue collection as an internal measure to raise resources however the International Budget Partnership (IBP 2017), Local revenue collection by counties remains erratic. This is due to system in relation to the types of revenue collected or the systems used to collect them leading to greater dependence on national transfers.

On the other hand, County governments according to (IBP 2017) are setting more realistic targets over time. In 2013/14 counties were able to collect only 49 percent of their local revenue targets. This improved to 67 percent in 2014/15 and 69 percent in 2015/16. The report further revealed that despite the lack of consistent revenue performance, overall revenue collection in all the years under devolution is higher than what was collected by local authorities in 2012/13.

\subsection{From Exclusion to Inclusion}

Today, all people including the marginalized and minorities can reap the benefits of self-governance and manage their development and affairs. The realization of citizen participation in decision-making is likely to positively contribute to political stability, improved governance and improved citizens' welfare (Hope 2014). For instance, KIPPRA and NGEC report (2017) revealed increased government funding towards the hunger Safety Net Program in marginalized/minority area in the country.

Marginalized community as cited by Cottrel-Ghai et al. (2013) must be outside the integrated social and economic life of Kenya as a whole, while minorities are groups that are: numerically inferior to the rest of the population of a state. Inclusion has reduced the continued use of minority by politicians as a proxy for ethnicity and calls to action for political competition.

The county government work towards improving the economy to reduce poverty, minimize the differences in income opportunities and access to social services, paying special attention the most disadvantaged in the community. Cornell and D'Arcy (2016) confirms that a number of smaller ethnic groups who have never had significant access to national resources now do so via their home counties.

Article 91 of the 2010 Constitution emphasize the importance of political participation stating that every political party shall respect the right of all persons to participate in the political process, including minorities and marginalized groups. Political participation entails inclusion of marginalized and minority groups such as women and special interest groups who include youth and persons with disabilities (Cottrel-Ghai 2013).

Through participation, the community is empowered to monitor and evaluate the county government's compliance with the decisions made and demand speedier government operations as well as push local institutions to enhance their capabilities in undertaking functions that have not been usually performed well by the national government. By doing so, the community will have the feeling of belonging thus embracing the development in the society.

Hope (2014) adds that participation in decision-making can also result in more flexible and effective administration since the county governments can tailor their services to the needs of the various groups in the county. The county government has a better understanding of community needs, and is therefore better placed in delivering relevant and responsive services. 
Inclusion reduces the distance both geographically and bureaucratically between governments and the citizen in terms of cost of service delivery. On the other hand, it increases the speed and efficiency with which local governments respond to the needs of the local community (Hope 2014). The citizens can easily walk to relevant office at file their complaints if there is any and they can also access services at the local office.

Report by UNDP revealed that 47 county governments adopted public participation and civic education guidelines to anchor civic engagement in county processes including county planning and budgeting. Public participation was enhanced through facilitation of public participation forums and development of public participation frameworks.

Hope (2014) insist that focused local development programs that are locally conceived have a much greater impact on reducing rural poverty and improving human development than broader and more generalized national programs originating from the center. This forms the basis of devolution whose main a gender is geared towards development.

Report by KIPPRA and NGEC (2017) on status of equality and inclusion in Kenya, 2015 revealed Nairobi County leading in equality and inclusion while Turkana and Wajir counties are the least. The progress has been made since the adoption of Constitution 2010. However citizen participation has been critical especially in decision-making with regard to national policies, laws and the strategies for development and implementation.

Special Interest Groups (SIG) such as children; the youth; women; people with disabilities (PWDs); older members of society; and minorities and marginalized are still underrepresented at both levels of government. This is due to failure by the government to implement electoral rules in party nominations which has negative effect on SIGs candidates.

\subsection{Informed Decision Making through Public Participation}

Decisions made at county level focus more on the local needs. This is enhanced by the ability of county members to engage into meaningful discussions in regards to running and management of the affairs of the county. Identification of specific problems affecting the community should be given priority. County management through public participation as provided for in the constitution should provide for opportunities for focused and prioritized community concerns to be addressed.

Public policy-making aspect as identified by Parliamentary Service Commission (2017), guidelines for evidence use in policy analysis and decision-making identified three factors that influence decision-making. However the local and international contexts within which policy decisions are being made, including the political context, socio-economic context, and cultural context and the evidence or knowledge available on the policy issue, and the prevailing framing of the issue in development discourses locally and internationally are very significant country development.

The County Integrated Development Plan (CIDP 2018) provides information on development priorities that informs the annual budget process based on the Public Finance Management Act which states that no public funds shall be appropriated outside a county's planning framework. The CIDP (2018) report further revealed that the county planning unit has the mandate to include, both in the draft and approved CIDP, relevant information to promote civic education and deliberations by the public and other stakeholders.

According to Embassy of Sweden and Diakonia (2016) report on what is public participation, through participation, there is promotion of sustainable decision-making by recognizing and communicating the needs and interests of the community. It also facilitates the involvement of those potentially affected by or interested in a decision. It is important to note that that the community contribution influences decision making by the authorities.

County governments that work together with non-state actors in decision making processes are likely to promote shared responsibility and partnership as well as providing complementary authority. The community becomes informed on the outcomes and the progress of the process and discussions thus improving development. For instance Report by AFIDEP (2016) on evidence informed policy making in Kenya's health sector revealed that policymakers in Kenya are prioritizing evidence use or consideration in decision-making

The CIDP (2018) emphasizes on the accessibility accuracy, and verification of data to help in prioritization process and subsequent deliberations on the development strategy. The report further states that the priorities proposed by the community members through consensus and voting should be considered.

Through citizen power as highlighted by Embassy of Sweden and Diakonia (2016), communities can engage in negotiations with their leaders in the county and also get involved in decision making responsibilities. The community must be fully involved in decision making process. However the report challenges the community to always ask and gauge themselves at what level of participation their leaders are involving them in decision-making, and also always aim to participate in county activities.

\subsection{Promotion of Transparency, Accountability and Democracy}

People at the grassroots get to choose their leaders and directly participate in decision-making processes making room for accountability and democracy. Accountability according to Sihanya (2012) is one of the cornerstones of 
good governance and requires the due performance of tasks or functions by an individual or agency. This is achieved when persons in authority are answerable for their actions and also when there is transparency in leadership.

There are various legal frameworks for accountability in the management of public affairs in Kenya. They include: the Constitution of Kenya of 2010, Public Officer Ethics Act of 2003, Civil Service Code of Regulations of 2006, Leadership and Integrity Act of 2012, Anti-Corruption and Economic Crimes Act (Cap. 65) of 2003, Public Procurement and Disposal Act of 2005 and Public Finance Management Act of 2012 (Institute of Economic Affairs 2015).

One of the objects of devolution is to promote democracy and accountability of exercise of power. Similarly devolution gives powers of self-governance to the people and enhances the participation of the people in the exercise of the powers of the state and in making decisions affecting them.

According to Hope (2014), devolution is used for a variety of reasons, especially democratization and improving governance, however it emphasizes on accountability by bringing participation and decision-making closer to the people Hope (2014) argues that closer proximity of devolved governments to the citizen has increased transparency in the use of local resources and strengthens downward accountability mechanisms, resulting in a decrease in corrupt practices.

He emphasize that devolution provides a much more manageable, transparent, and accountable arena to prevent corruption from erupting or to control it if it does. The author regarded devolution as an important element of combating corruption in countering the lack of transparency and accountability in previous centralized systems of government.

UNDP has been supporting Kenya's efforts towards achieving the democratic system that is issue-based, people-centered, results-oriented and accountable to the public. UNDP is working with stakeholders towards the realization of the governance reform aspirations under democracy and public service delivery among other strategic areas.

World Bank through the Kenya Accountable Devolution Program (KADP) works with government at both county and national levels. The program addresses key capacity gaps to make devolution respond to citizens' needs through strengthened institutions, improved service delivery and citizen engagement.

For instance, the introduction of participatory budgeting, county governments are able to allocate a portion of their development budget for projects that are identified and eventually selected by the community itself. Counties are now able to go where the people are and to effectively bring out the voices of all citizens including women, youths and marginalized groups (World Bank 2018).

A fundamental principle of democracy according to Institute of Economic Affairs (2015) is that citizens have the right to exact accountability and public officials have a duty to be accountable. Abuodha (2011) insists that one of the hallmarks of a truly democratic society is a culture of openness in which government places utmost importance in making itself amenable to public scrutiny of its activities at all times, by actively making available information on the functioning of every aspect of its governance machinery.

He further states that communities must be able to use performance monitoring to observe the implementation and performance of local projects, public services or programs. Similarly, Institute of Economic Affaire (2015) insists that county public officers have a duty to be accountable to citizens in the management of public affairs, including the use of public funds and the delivery of services. In addition, citizens in the counties, not only have the right to have their socioeconomic rights realized within available resources, they also have the right to exact justifications for how public resources are used in realizing these rights.

\subsection{Promotion of National Unity}

By reducing the power of the central government and distributing it equally among the counties, the devolved systems hope to achieve national unity. Article 174(b) of the constitution, under the objects of devolution states that, devolution of government aims at fostering national unity by recognizing diversity.

According to Hope (2014) devolution has the ability to contribute to national unity and political stability. This is a very important benefit which contributed towards voting for the 2010 constitution by many Kenyans. One of the functions of the decentralized government is to foster unity, cohesion and co-existence among communities. Ambose (2017) emphasized on the importance of understanding the meaning of national unity in the context of harmony, accord, and mutual agreement or co-existence among different entities.

Amboso (2017) is optimistic that if devolution is well watered and natured, it is capable of enhancing unity of Kenyan citizens' diversity. However the peaceful co-existence of Kenyans must embrace the diversity that is traced in a number of ways such as race, ethnicity, religion, gender, culture and language. This is provided for in Article 130(2) of the constitution 2010 which recognizes the dimension of spatial diversity.

According to Cornell and D'Arcy (2016), the explicit goals of devolution reforms in the constitution include inculcating a sense of Kenyan identity and strengthening national unity done by recognizing diversity; ensuring equity in allocation of resources and providing justice for marginalized communities and regions. Devolution is 
designed to create a more equal playing field for all communities.

Hope (2014) further adds that there is a persistent belief that local democracy is necessary for national unity especially in countries with great social diversity and regional disparities, such as Kenya.

Ambose (2017) concluded that one of the objects of devolved government, which may be as a cure to national unity as provided for under Article $174(\mathrm{~g})$ has to ensure equitable sharing of national and local resources throughout Kenya. This will ensure that all regions throughout Kenya shall experience development regardless of whom and/or which ethnic group leads the country meaning devolution has to a large extent enhanced national unity in our diversity.

There are a number of factors provided for in the constitution that ought to unite Kenyans. They include: use of Kiswahili as the national language and English as official language as provided for under Article 7(1) and (2), the national symbols and national holidays under the provisions of Article 9, permits Kenyans from all walks of life to assemble, come together to remember the progress the nation is making as a whole in the case of National holidays.

Ambose (2017) however warns that national unity and cohesion have been compromised by feelings of inequality, social injustice, regional disparities, and marginalization. Similar sentiments were raised by Khaunya, Wawire and Chepng'eno (2015) when they stated that devolution could potentially undermine national unity governments and breed apprehension amongst communities considered aliens in the Counties.

However, Hope (2014) is optimistic that the process of devolution envisaged in the 2010 constitution was, at the outset; seem very complicated as well as a daunting task. However, the benefits of this exercise will, in the long-run, far outweigh any potential implementation problems.

\subsection{Disadvantages of Devolution}

While devolution has had its pros, Kenyans have also witnessed its shortcomings. Some of the weaknesses of devolution are:

\subsection{It is expensive due to diversity of roles}

The introduction of more seats (67 senators, 47 governors and 2,526 member of assemblies) means that the taxpayer is at a loss since the wage budget increased significantly. This was due to simultaneous process of devolving administrative, political structures and resources.

According to Kinuthia and Likin (2015) the total cost of running counties in 2015/16 was about Ksh 48.5 billion whereby the average cost of running a county is Ksh 1.03 billion, with costs ranging from Ksh 695 million (Isiolo and Lamu) to Ksh 1.80 billion (Nairobi). On the other hand lack of audit of the resource requirement in all counties made the devolution process expensive since the cash transfers was not based on factual figures as reported by KHRC.

The report on Kenya Devolution Taking Stock One Year On by KHRC further revealed that immediately the devolved system was introduced, the members of parliament and county representative assumed office. However their first item on the agenda was to agitate for higher pay despite the Salaries and Remuneration Commission's recommendations. Members of County Assemblies (MCAs) had their salaries raised from Kshs 79,000, upon assuming office, to Kshs 225,000 per month.

Kenya's public Wage Bill (WB) was estimated at 12.1\% of Gross Domestic Product (GDP) in 2013 (approximately 50\%) of the country's total revenue. It was reported to be higher than the internationally accepted levels of Wage Bill in GDP ratio and the Wage Bill to revenue ratio which is documented as $7 \%$ and $30 \%$ respectively (KHRC)

Kenya's members of national assembly are the highest paid civil servants with the monthly salary of Kshs. 850,000 termed as the highest wage differential in the whole world (report by the KHRC). It was estimated that the taxpayers incurred an extra 103 billion for 5 years. Moreover, the amount is minus monthly allowances of between Kshs. 100,000 to 200,000 per month.

The devolution system became even more expensive when there was no elected women MCAs forcing parties to nominate women to adhere to the two-thirds gender principle. Furthermore individual MCAs were hiring 3 to 10 staffs to man the 4450 ward offices countrywide. Due to this, counties with many wards and those with large county executive committee experiences higher administrative costs (Kinuthia and Lakin 2015).

As if that was not enough, County government spends cash on unnecessary purchases like ipads. For instance in the 2014/15 budget, MCAs set aside 3.6million to purchase ipads, and 2.6 billion was spent on foreign travels. World Bank (2011) concluded that how much money counties need, will vary depending on how the transfer of functions is sequenced and it is important that counties receive enough money to fund those functions.

3.2 Mismanagement of funds allocated to county governments

Some county governments have been in the spotlight for misappropriating funds while most counties cannot account for the money allocated. Article 201 of the Constitution provides basic financial management principles 
as openness; accountability; equity; public participation in financial matters; prudence; and responsible use of public resources.

Public Finance Management Act 2012 (PFM) on the other hand was enacted to provide for the effective management of public finances by the national and county governments. In addition counties established County Finance Act to strengthen management of finance at the county level.

Khaunya, Wawire and Chepng'eno (2015) insist that with a constitutional guarantee of unconditional transfers from the center, Kenya's counties have the means and the autonomy to address local needs. The national treasury disburses funds to the counties as stipulated in the constitution. However it has been noted that there is mismanagement of funds meant for devolution. According to Ndalila (2016), this is due to inadequate qualified and experience staff to implement the structures set in place by the PFM Act.

He further stated that lack of established county infrastructure as well as lack of public participation guidelines permitted greedy officials to take advantage of the gaps and loopholes in the implementation process to mismanage the public funds. It is critical for citizen to left out in preparing the budget and distribution of funds to various projects in the county. Where citizens are not included, there are high chances of officers to channel funds into projects that will benefit their personal interests and not the community.

In addition, the poor coordination of financial services between the counties and the national governments also contributes to mismanagement of funds. Finally, Ndalila (2016) argues that the legislative framework set by the PFM Act falls short of international best practices allowing officers to mismanage funds.

Although there have been laws in place in regards to finance management, accounting for disbursed funds has been a challenge to many counties. According to Ndalila (2016), counties did not allow for development of capacity, in training modern public finance management techniques and also the office of the accountant-general was not properly resourced and funded to fulfill its function.

\subsection{Duplication of roles}

Currently, more people are doing the same job. Therefore, the chances of misusing powers and wasting resources are higher. Beginning 2014 to 2016, Kenya witnessed a lot of back and forth between the National Assembly and the Senate. For some, it is hard to distinguish between the role of the senators and the MPs.

Duplication of duties has led to internal political supremacy wars considering that some of the officers were hired by CPSBs, others posted by the national government, another set of staff were hired through the Transition Authority, while some were drawn from the former Local Authorities. Some of their roles have not been clearly demarcated and hence there is redundancy in some cases (Khaunya, Wawire and Chepng'eno 2015).

Due to this, county public administration and service delivery systems is affected mainly because of overlapping jurisdictions as well as functions. For example the role County Commissioners vis-à-vis the Governor, the sub County Administrator vis-à-vis sub County Commissioners, Chiefs and Assistant Chiefs. This has bred mistrust and a potent source of conflict (Khaunya, Wawire and Chepng'eno 2015).

It is clear that duplication of roles in devolved system in Kenya is a challenge that was noted by Council of Governors (COG) one year after the kick of devolution. The COG tried to stop it by presenting a case in court as revealed below: The Petition No. 381 of 2014 challenging the constitutionality of the CDBs was lodged whereby the petitioner wanted the Court to declare the provisions of Section 91A of the CGAA, which vests various functions in the CDBs, unconstitutional for violating Articles 6(2); 95, 96, 174(1), 175, 179(1), 179(4), 183(1), 185(3) and 189(1) of the Constitution. The basis of the challenge is that through the CDBs, Senators and members of the National and County Assemblies would be undertaking executive functions at the County level (Kenya Law 2014).

The County Governments (Amendment) Act (No.2) permitted the e establishment of the CDBs that places the coordination and harmonization of role of county development plans and projects within the ambit of the CDBs. The Act intended to provide CDBs with the power to consider and adopt county integrated development plans and county annual budgets before they are tabled in the County Assemblies for approval. The process of coordination, harmonization, adoption and approval of county development plans and county annual budgets affects the functions and powers of the county governments (Kenya Law 2014).

The Court then concluded that "thus, we are convinced that the involvement of the Senate, National Assembly and national executive in the $C D B$ violate the tenets and principles of the Constitution in three fundamental respects. First, it interferes with and compromises the roles of these organs in the exercise of their oversight functions over the functioning of counties and the use of revenue allocated to them. Secondly, and critically, it undermines the principle of devolution, a key cornerstone of the new Constitution and the governance structure of the country. Thirdly, it is in violation of the principle of separation of powers (Kenya Law 2014).

The devolved system faced a lot of challenges that lacked clear defined structures, processes, guidelines or role clarity. For instance health sector has been struggling due to lack of organogram for the county health department. This led to the emerging of two levels of management struggling to coordinate with each other, and also unclear roles and lines of accountability between them i.e SCHMTs and the CHMT (Nyikuri et al 2017). In 
addition, duplication of roles was exacerbated by lack of systems for instance financial allocation that affected allocation of funds to lower level institutions, including SCHMTS, hospitals, health centers and dispensaries. There is need to guard against duplication of duties. This will require personal initiative and a collaborative approach, conduct civic education and technical support (Institute of Economic Affairs, 2013)

\subsection{Uneven Development}

Some counties such as Nairobi, Nakuru, and Mombasa, already had a head start, development wise. These counties have better infrastructure and public utilities as well as opportunities for employment and investment. It will take extra efforts and some years for other counties to catch up.

This means that people's needs vary between the arid and semi-arid North, the highlands, the rural Northern Rift, the urban centers of Mombasa, Nairobi, and Kisumu, the Coast, and Western Kenya. Giving example of health, Khaunya, Wawire and Chepng'eno (2015) insist that counties that are lagging behind need to catch-up in providing basic health services. On the other hand leading urban counties will be faced with new types of diseases mostly non-communicable such as diabetes and cancer.

World Bank (2011) emphasizes that economic activity are concentrated in specific geographic areas. The report pointed out Nairobi and Mombasa as leading urban centers which accounts for the bulk of Kenya's total production. The report further revealed that eighty percent of Kenya's economic activity is generated by only one half of Kenya's counties i.e. 23 out of 47.

Counties in marginalized regions lack in key infrastructural developments hence they receive less than they should according to the CRA ratio and the equalization fund have failed to properly address these development gaps. (Khaunya, Wawire and Chepng'eno 2015).Such counties have taken off at a relative disadvantage and it may take time to build up their capacity and ability to use resources well.

According to SID (2011) the reform is likely to deepen inequalities despite devolution frameworks incorporating affirmative action. SID recommended for the need for an eclectic design and implementation of devolution that considers the objective initial circumstances of the prospective devolved units, rather than employing a single national framework and timetable that are insensitive to variations in circumstances. Similarly, World Bank (2011) suggested the need for particular assistance to some counties to help them catch-up.

Counties in the remote and marginalized areas will take longer time to develop since the national government does not allocate sufficient resources to assure a basic level of service delivery to their citizens (World Bank 2011). These counties need additional resources if service and infrastructure gaps are to be closed.

World Bank (2011) insists that it is not realistic to expect all counties to reach the same level of economic development. The universal development can be reached when the country experiences growth in its income. At this point, there is sharing of the benefits of economic development with the whole population through social services benefiting all citizens.

\subsection{Challenges of Devolution in Kenya}

\subsection{Interference with the Responsibilities of Institutions involved in Devolution}

The decentralization of government serves several fundamental functions as provided for in the constitution 2010. Here are some of the functions: equitable sharing of national and local resources, promoting accountability, transparency, participation and decision making at grass-root level, granting rights to communities to manage their own resources, bridging economic and social inequality gaps by decentralizing state organs and public resources to enable ease of access to public services and fostering unity, cohesion and co-existence among communities. In order to achieve this, there has to be enabling environment for service delivery with the necessary capacities, systems, and regulations at county level.

Article 187 of the Constitution provides for the transfer of functions and powers between National and County Governments. Report by the Kenya Institute of Public Policy Research and Analysis (KIPPRA 2016), revealed that government ministries reviewed their policies to facilitate devolved system of governance however, the mode of cascading the same to counties was not highlighted. Further the report revealed that there are bills relating to counties that are passed and assented by the President without inputs from the Senate affecting the role of the Senate.

Article 174 of the constitution established the following institutions to facilitate the achievement of the objects of devolution: the parliament and the legislative assemblies in the county governments, the National Executive, the executive structures in the County Governments, the Judiciary and Independent Tribunals, Commissions and Independent Offices (Ministry of Devolution and Planning 2016).

The mandate of CRA is to give recommendation on revenue allocation; however this has been proved to be a divisive issue. The law entitles counties at least 15 per cent of the total National Revenue collection. Despite many counties receiving the funds, there is still a feeling that budgetary allocations need to be increased, and that the national government is reluctant to increase funds (Standard Media 2016).

The 2017 CRA press release to media revealed the challenges the commission is facing in regards to execution 
of its mandate. "The Commission recommended Ksh. 323 billion and the National Treasury Ksh.299 billion for counties. However, the National Assembly published the Division of Revenue Bill 2017 allocating county governments an equitable share of Ksh. 291 billion. The Senate rejected the National Assembly Bill and instead published the Bill allocating counties Ksh.314 billion, resulting in an impasse. The first attempt at mediation collapsed and the bill was defeated".

The Inter-Governmental Relation Act 2012 provides framework for consultation, cooperation and dispute resolution between the national and county governments and amongst the county governments. However, Devolution Policy (2016) revealed conflict between the two levels of government due to conflict of laws especially laws that were established prior to the promulgation of the Constitution.

Although the intergovernmental sector forums were established to handle issues of common interest to the National and County Governments, the administrative procedures for establishing and managing intergovernmental sector forums and enforcement mechanism for forum decisions are lacking. Also the decisions of the forums are not binding. The Intergovernmental Relations Technical Committee cannot effectively discharge its mandate due to lack of regulations to give effect to the Act. According to Devolution Policy (2016) the regulations have not been developed.

Speech by H.E Josphat Nanok Chairman, Council of Governors and Governor Turkana County (2017), revealed poor or lack of consultation on matters that affect County Governments. Through Intergovernmental Relationship Act 2012the two levels of government are distinct and inter-dependent and are expected to conduct their mutual relations on the basis of consultation and cooperation.

The standard Media report 2016 revealed that there should be sign-posting of issues that relevant authorities and stake holders will be ill -advised to ignore if we want to effectively complete devolution process whose start has neither been the best nor the worst. The institutions involved in devolution process for instance The Transition Authority (TA), Commission on Revenue Allocation (CRA), Ministry of Devolution and Planning (MoDP), and The Council of Governors $(\mathrm{CoG})$ should effectively play their role to bring to the realization of the devolution system.

Article 190 of the constitution as stated in Devolution Policy (2016) given effect by Section $121-130$ of the County Governments Act, 2012 which provides for support to the County Government by National Government to enable them perform their functions. The governors expressed their dissatisfaction with pretense support from the National Government. "We need to see goodwill and genuine support from the National Government Ministries, departments and state agencies being sufficiently provided to the County Governments" (H.E Josphat Nanok Speech 2017).

Report by the Standard Media (2012) envisioned the trouble ahead even before the country adopted the devolved system of governance in 2013. The report the constitutional commissioners warned the central government and parliamentarians are slowly taking over the powers of county governments even before they are set up. The commission for revenue allocation, the commission for the implementation of the constitution and the transitional authority wanted the national government to support devolution as provided for in the constitution.

\subsection{Insufficient Allocations and Delayed Disbursements of Funds to Counties}

County governments have experienced delays in funds disbursement from the National government. This is evident in the Standard Media report (2017) on County funds is held up at the Treasury. The report revealed that the operations of county governments could be affected as the national government continues to hold more than Sh50 billion in equitable share meant for the devolved units. The funds were part of the Sh329 billion approved by the National Assembly for disbursement to the 47 counties in the 2017/18 financial year where Sh77.4 billion was meant for disbursement in the first quarter.

The same report further revealed that the County Governments had not received their monthly disbursements dating back to the month of July 2017 when the 2017/2018 financial year came into effect. Due to this some County Government attempted to introduce new levies however this was prohibited when the treasury published the County Governments Revenue Raising Regulation Process Bill 2017.

Funds disbursement delays led to the launch of spirited campaign by some governors that perceived national government reluctance as a ploy to frustrate the effectiveness of devolved units. Devolution Policy (2016) revealed that the decentralization process in many counties has not been fully operationalized due to inadequate resources.

Speech by H.E Josphat Nanok Chairman, Council of Governors and Governor Turkana County during the induction of governors and deputy governors in December 2017 revealed that there have been disagreements between County Governments and the National Government over funding for County functions. County Governments experienced insufficient allocations and delayed disbursements of funds to Counties by the National Treasury which nearly paralyzed finalization of development projects. Also there are functions that remain unfunded yet they have already been transferred to the Counties.

In 2017, County Allocation of Revenue (amendment) Bill into law and treasury was expected to release Sh77.4 billion to the 47 County Governments, however the disbursement was delayed due to technical hitch arising 
from a stalemate between the two Houses that meant some amendments had to be made on the County Allocation of Revenue Act (CARA) (Report by Business Daily 2017). Senators accuse Treasury Cabinet Secretary Henry Rotich of derailing the operations of counties. Similar sentiments were raised by Council of Governors through their chair Governor JosephatNanok (Turkana) who accused the CS of sabotaging the counties.

The recent report by Capital FM (2018) revealed the recommending by Treasury to reduce budget allocation to county governments. Treasury through its Cabinet Secretary Henry Rotich said this during his presentation to the Senate Committee on Finance and Budget.

\subsection{Insufficient Public Participation/Gender inequality}

Public participation is a national value and principle of governance established in Article 10 of the constitution. Article 232(d) guarantees the involvement of the people in the process of policy making, however, the level of citizen involvement at both levels has not been optimized (Devolution Policy 2016). This is due to lack of policy and legal framework to guide the conduct of public participation.

TISA (2011) report on Policy Proposals on Citizen Participation in Devolved Governance in Kenya revealed the need to build the capacity of citizens to enhance their participation in the management of local affairs and projects, and to hold duty bearers accountable. The report further gave detailed information about public participation.

There are two ways of public involvement, indirect and direct involvement. Indirect involvement is when the electoral officials and professional administrators act on behalf of the citizens in a representative democracy. On the other hand direct involvement is when the citizens are the owners of the government and should be involved in the decisions of the State (TISA 2011). Citizens should play the role of administrative decision-making and decision-making in service delivery.

Participation permits citizen to exercise of the power and participate in making of decisions affecting them. Article 232(d) guarantees the involvement of the people in the process of policy making (Ministry of Devolution and Planning 2016 report). The report further revealed that there is no policy and legal framework to guide the conduct of public participation. Although counties have public participation legislation, these have been found to be weak and ineffective in promoting quality public participation.

Devolution system and structures is affected by low citizen involvement. However to engage effectively, citizens not only need an awareness of their roles and responsibilities but knowledge and skills on how to execute the responsibilities (TISA 2011).

The constitution 2010 established the two-third gender rule in Article 81(b) of the Constitution however this was not observed. "Not more than two-thirds of the members of elective public bodies shall be of the same gender," but there has been no consensus over the three proposals that have been put forward to meet the requirement (The Standard Media 2016).

The law was designed to ensure adequate representation of women and other historically marginalized groups in the devolved structures however this was not met. These challenges do pose great risks for the effective roll out of devolution in Kenya and also provoke some critical questions about the current implementation strategy. Devolution was established as a pathway to equal development across the Country however the process is threatened by factors mentioned above. There is need to address these challenges by providing solution. According to UNDP (2015) the policies and legal framework for devolved governance should be strengthened.

\subsection{Corruption/ Mismanagement of Funds}

Corruption is real in county governments as reported by Ethics and Anti-Corruption Commission (EACC 2014) during their $4^{\text {th }}$ Governance Integrity and Investment Conference presentation in Mombasa. This was based on the following evidence: corruption reports received and currently under active investigations at EACC, intelligence information on operations of some county officials currently being processed at EACC, KENAO reports revealing misuse of funds, increasing public outcry and stakeholder concern and investigative media reports.

The presentation further identified high corruption risk areas in County Governments as follows: recruitment of personnel, county public procurement, county financial management, planning and management of county projects and county legislative duties. The EACC also identified common forms of corruption in County Governments as tyranny of ghosts: ghost projects, assets, liabilities, procurement and payroll, conflict of interest, bribery, abandoning existing infrastructure in favour purchasing or renting at exaggerated costs, procurement of goods and services not budgeted for or exceeding budgets among others. I addition bribery was termed as the most prevalent form of corruption in public service delivery.

Report by the Star (2015) revealed corruption as the greatest threat to devolution, according to a survey by Transparency International. The poll that was carried out in 16 counties between March 22 and April 6cited Graft at 59 per cent. The Standard Media (2017) reported corruption as the biggest threat to devolution and the most pressing problem county governments should address. The article was published after the report on the survey that was conducted by Transparency International Kenya in July 2016 was released. 
The same report revealed how county officials were looting public coffers through irregular dealsand shady procurement contracts. Similar issue was raised in 2014 by Auditor General. In 2017 the President warned governors stealing public resources (Report by the Standard media 2017. Corruption

Survey by Transparency International as reported by the Star (2015) revealed that majority of the respondents were unimpressed by service delivery with regard to the 14 devolved functions due to corruption and mismanagement of available funds. It further stated that mismanagement of public funds in the counties has also been periodically mentioned in reports by financial oversight organs like the auditor-general, the Controller of Budget and the Commission on Revenue Commission (The Star 2015).

The mindset of 'get-rich-now' among some officials in the counties has also contributed to misuse of public funds through unnecessary domestic and foreign trips. Improper procurement procedures have contributed to corruption. For instance report by the Standard (2015) revealed how county government procured a pipette for artificial insemination that costs Sh30 at an inflated cost of Sh875 per piece. County governments were blamed of neglecting development as apriority but instead, they put money where it can be siphoned off. The report further stated that the oversight over public expenditure in the counties have lost meaning in most counties.

\subsection{Lack of Capacity to Facilitate Services Delivery}

Report by the Standard media (2016), revealed that there is lack of understanding of key issues around devolution that is generating a great deal of mistrust among stakeholders. The report further stated that some counties, for example contested the piecemeal transfer of functions arguing that all powers provided in Schedule Four of the Constitution be transferred at once. However, the reality is that many county governments lack the capacity to absorb all such powers within a short period.

Despite efforts to address the capacity needs of the counties, there still exist skills gaps in the public service. Due to this, there is inadequate capacity at both levels of government to implement their respective mandates and functions (Devolution Policy 2016).

The major challenge has been noted as the lack of capacity by many counties to deliver on the devolved functions. This has largely been attributed to the lack of coordinated manner in which functions were transferred. The other challenge is the lack of strong intergovernmental relations mechanism between the two levels governments and even between counties thus creating vacuum that eventually creates conflicts (Speech by the Principal Secretary, State Department of Devolution April 2016).

The UNDP (2015) recommended for strengthened and aligning capacities at national and county levels. This should be achieved through capacity development which is also a process that requires continuous and targeted capacity support to people and systems. Continues training especially skills transfer that addresses the capacity gaps identified by county governments is required. The support should target mid and lower cadres of the public service at county levels to ensure that the county public service is functional and adequately informed to support implementation of Devolution.

There should be enhanced service delivery mechanisms and resilience for peace building and conflict prevention. Counties should identify and address challenges affecting service delivery at local level given their proximity to the people (UNDP 2015). The County government should strengthen citizen engagement in devolved governance. This will help to ensure that people's needs are addressed.

\subsection{Summary and Conclusion}

Decentralization of power to counties is what defines devolution system of government in Kenya. (Article 6 (2) of the constitution allocates functions and powers to National government as well as County government. Article 189 (a) requires government at either level to perform its functions and exercise its powers. Through the institution established by law to implement devolution, their mandate is threatened affecting their performance. Issues emanating from these institutions have great impact to devolution process.

Insufficient financial allocation to counties is affecting the achievement of devolution in Kenya. The back and forth between the parliament approved budget, the Commission of Revenue Allocation and the National Treasury has caused delays in disbursement of funds to counties. Through the CoG counties have raised this issue which most of the time has caused disagreement between the two governments. The governors have blamed national government for sabotage of devolution.

Although the blame has been on National government for tampering with implementation of devolution process, the county government is also to blame. High rate of corruption has been experienced at county level. County governments have failed to implement public participation a mandate provided to them by the constitution. The employment process in counties is based on tribalism and nepotism. This has affected the performance of most counties.

Devolved system of government was ushered in immediately after the March 2013 general elections. However the implementation process slightly delayed until November 2013 . The process is slow due to challenges which some were envisioned even before the devolved system of government was adopted. The central 
government's ongoing reaction to the devolved system of government may continue to try to put the break on the process and reassert central control.

Disagreement between the two levels of governments is common despite the establishment of Intergovernmental Relationship Act to resolve issues between the governments. Insufficient funds allocated to County government have affected delivery of services in counties. Delays in disbursement of these funds have become a common trend, however the National Treasury has not been held accountable for it.

On the other hand challenges emanating from lack of capacity and skill has affected the service delivery in many counties. This is due to tribalism and nepotism experienced at county level which in most cases determines who is to be employed. Unqualified people end up occupying jobs they do not have skills for thus affecting service delivery. High corruption in County Governments is common in recruitment of personnel, county public procurement, county financial management, planning and management of county projects and county legislative duties. County governments have the mandate of facilitating the public participation but this has been optimal. These challenges can be addressed if all involved parties are given enabling environment to perform their functions.

\section{Reference}

Abuodha, J.(2011). Integrating Accountability Mechanism in Local Government: a Case of Kenya Specialized Intellectual Property Rights Court Regime.Available at www.kenyalaw.org. Accessed on $6^{\text {th }}$ June 2018.

AFIDEP(2016). Evidence-Informed Policy-Making in Kenya's Health Sector: TheDevil is in the QulaityOf Evidence. Available at www.afudep.org.Accessed on $15^{\text {th }}$ June 2018.

Ambose, E.S.(2017). The Impact of Kenya Devolution on National Unity in Diversity.Available at www.linkedin.com.Accessed on $16^{\text {th }}$ June 2018.

Business Daily (2017) Treasury Set to Disburse Shs 77.4 Billion to Counties. Available at www.businessdailyafrica.com.Accessed of $17^{\text {th }}$ March 2018.

Capital FM (2018). Government to Cut Allocation to Counties Due to a Sh70B Shortfall.Available at www.capitalfm.co.ke/business/2018/03/.Accessed on $18^{\text {th }}$ March 2018.

CIDP. (2018). 9 Key Questions About Your County Integrated Development Plan. Available at www.internationalbudget.org.Accessed on $25^{\text {th }}$ June 2018.

CoG and Ministry of Devolution and planning (2017). Joint Communiqué at the End of the Fourth Annual Devolution Conference Held From $6^{\text {th }}$ to $9^{\text {th }}$ March 2017 at Kenya Wildlife Services Training Institute, Nakuru County. Available at www.daogewe.org. Accessed on $28^{\text {th }}$ March 2018.

CoG (2015). State of Devolution Address by H.E Peter Munya.Available at www.cog.go.ke/46-news-highlightsold.Accessed on $25^{\text {th }}$ March 2018.

CoG (2017). Remarks by H.E. JosphatNanok, Chairman, Council of Governors and Governor Turkana County: Induction of Governors and Deputy Governors Diani Reef Beach Hotel, Kwale County $13^{\text {th }}-17^{\text {th }}$ december, 2017.

CoG (2017). Strategic Plan 2017-2022. Available at www.cog.go.ke.Accessed on 12 April 2018.

Cornell, A. \&D'Arcy,M.(2016). Devolution Democracy and Development in Kenya.Available at www.icid.se.Accessed on $20^{\text {th }}$ June 2018.

Commission of Revenue Allocation.(2017). Third Year of Devolution in Kenya: Successes and Challenges. Available at www.crakenya.org.Accessed on $13^{\text {th }}$ March 2018.

Commission of Revenue Allocation (2017).Restoring the Division of Revenue Act.Available at www.crakenya.org. Accessed on $13^{\text {th }}$ March 2018.

Cottrel-Ghai, J. et al(2013). Taking Diversity Seriously: Minorities and political Participation in Kenya.Av(2017). Analysis of Kenya's Budget 2017/2018: What's in it for the Poorest People? Available at www.devinit.org. Accessed on $20^{\text {th }}$ June 2018.

Embassy of Sweden \&Diakonia.(2016). What is Public Participation. Available at www.uraia.or.ke.Accessed on $16^{\text {th }}$ June 2018.

Ethics and Anti-Corruption Commission(EACC 2014). $4^{\text {Th }}$ Governance Integrity and Investment Conference: Combating Corruption, Unethical Conduct and Practices within the County Governments. Available at www.icpsk.com.Accessed on $25^{\text {th }}$ March 2018.

ElgeyoMarakwet County Gazatte Supplement No 1(2015). ElgeyoMarakwet Equitable Development Act.Available at www.kenyalaw.org.Accessed on $28^{\text {th }}$ May 2018.

Hope, R.K.(2014). Devolved Government and Local Governance in Kenya.Availabe at www.researchgate.net.Accessed on $15^{\text {th }}$ May 2018.

ICDL(2016). Devolution, Democracy and Development in Kenya: Research Paper 5. Available at www.icdl.se.Accessed on $20^{\text {th }}$ March 2018.

Institute of Economic Affairs (2013). Anchoring Devolution:The Acts and Basics in the Constitution( ABC). Issue No 15. Available at www.ieakenya.or.ke.Accessed on $4^{\text {th }}$ June 2018.

Institute of Economic Affairs (2015).Institutionalizing Social Accountability in Devolved Governance.Available 
at www.ieakenya.or.ke.Accessed in $4^{\text {th }}$ June 2018.

KHRC.Kenya Devolution Taking Stock One Year On.Available at www.khrc.or.ke.Accessed on $15^{\text {th }}$ June 2018.

Kenya Law (2010).Laws on Devolution.Available atwww.kenyalaw.org.Accessed on $13^{\text {th }}$ March 2018.

Kinuthia, J. \&Lakin, J. (2015).How Much Does it Cost to Run a County. Available at www.internationalbudget.org. Accessed on $18^{\text {th }}$ June 2018.

Kinuthia, J. \&Lakin, J. (2016). Sharing Public Resources Within Counties in Kenya. Available at www.internationalbudget.org. Accessed on $16^{\text {th }}$ June 2018.

Khaunya, F.M., Wawire, P.B. \&Chepng'eno, V.(2015). Devolved Governance in Kenya, Is it a False Start in Democratic Decentralization for Development? Available at www.ejournalofbusiness.org. Accessed on $18^{\text {th }}$ June 2018 .

KIPPRA (2016).Status of Devolution in Kenya Consolidated Report.Available at www.kippra.or.ke.Accessed on $18^{\text {th }}$ March 2018.

Ministry of Devolution and Planning \& UNDP (2016).Policy on Devolved System of Government.Available at www.devolutionplanning.go.ke.Accessed on $17^{\text {th }}$ March 2018.

KIPPRA.\&NGEC (2017).Status of Equality and Inclusion in Kenya.Available at www.ngeckenya.org.Accessed on $10^{\text {th }}$ May 2018.

KIPPRA (2018). An Assessment of Health Care Delivery in Kenya Under the Devolved System: Special Paper No 19. Available at www.kippra.or.ke.Accessed on $15^{\text {th }}$ June 2018.

Kenya School of Government and Ministry of Devolution (2015).Building Participation in Kenya.Available at www.openknowledge.worldbank.org. Accessed on $15^{\text {th }}$ May 2018.

Kimenyi, S.M. (2013). Devolution and Resources Sharing in Kenya.Available at www.brookings.edu.Accessed on $15^{\text {th }}$ May 2018.

Kivoto, E.M.(2016). Inter County Relationship in Kenya. Available at www.academia.edu.Accessed on $25^{\text {th }}$ April 2018.

Ministry of Devolution and Planning (2016). Speech by the Principal Secretary, State Department of Devolution, MsMwanamakaMabruki During the Inter- Ministerial Workshop at Great Rift Valley Lodge, Naivasha on $14^{\text {th }}$ April, 2016.

Ndalila, M.N.(2016). Strengthening the Management of Devolved Funds in Kenya: Bridging the Gap Between Law and Practice at the Counties. Available at www.erepository.uonbi.ac.ke.Accessed on $24^{\text {th }}$ June 2018.

Parliamentary Service Commission.(2017). Guidelines for Evidence Use in Policy Analysis and Decisionmaking.Available www.afidep.org.Accessed on 17 $7^{\text {th }}$ June 2018.

Society for International Development (2011).Devolution in Kenya New Constitution. Nairobi: The Regal Press Kenya Ltd.

Sihanya, B.(2012). The Role of Judiciary in Accountability and Governance Structure: A presentation to the Institute of Certified Public Accountant of Kenya $20^{\text {th }}$ Economic Symposium at Hilton Hotel Nairobi. Available at www.icpak.com.Accessed on $28^{\text {th }}$ May 2018.

SID. (2011). Devolution in Kenya's New Constitution.Available at ww.sidnt.org.Accessed on $20^{\text {th }}$ June 2018.

TISA (2011).Policy Proposals on Citizen Participation in Devolved Governance in Kenya.Available at www.tisa.or.ke.Accessed on $18^{\text {th }}$ March 2018.

The Standard Media (2016).Devolution Still Facing Challenges.Available at www.standardmedia.co.ke.Accessed on $13^{\text {th }}$ March 2018.

The Standard Media (2017). County funds are held up at the Treasury. Available at www.standardmedia.co.ke/business/article.Accessed on $13^{\text {th }}$ March 2018.

The Standard Media (2017).How grand corruption in the counties undermines devolution Available at www.standardmedia.co.ke. Accessed on $18^{\text {th }}$ March 2018.

The Star (2015).Corruption the 'top threat' to devolution.Available at www.thestar.co.ke/news/2015/07/03/corruption-the-top-threat-to-devolution.Accessed on $13^{\text {th }}$ March 2018 .

The Star (2015).Why Corruption Is Devolution's Biggest Enemy.Available at www.thestar.co.ke/news/2015/12/12/.Accessed on 20 $0^{\text {th }}$ March 2018.

UNDP (2015).Annual Progress Report 2015: The Integrated UNDP Support Programme to the Devolution Process in Kenya. Available at www.ke.undp.org.Accessed on 13 ${ }^{\text {th }}$ March 2018.

UNDP (2017). The Integrated Support Program to TheDevolutrion Process in Kenya: Mid Term Evaluation (MTE). Final Report.Available at www.undp.org.Accessed on $14^{\text {th }}$ June 2018.

World Bank. (2011). Special Focus: Kenya's Momentous Devolution. Ed No 5.Available at www.siteresources. worldbannk.org.Accessed on $20^{\text {th }}$ June 2018.

World Bank.(2018).Towards a More Inclusive Development in Kenya. Available at www.worldbank.org. Accessed $6^{\text {th }}$ June 2018. 